\title{
Characteristics and Career Plans of Korean International Students and Graduates of Doctor of Pharmacy Program in the United States
}

\author{
Yun Jeong Lee* \\ Laboratory of Clinical Pharmacy, College of Pharmacy, Dankook University, Cheonan, 31116, SOUTH KOREA.
}

\begin{abstract}
Introduction: This study was designed to identify the characteristics and career plans of Korean international students and graduates of the PharmD program in the United States. Methods: A questionnaire was administered to the online community of Korean international students and graduates of the US PharmD program. Results: Korean students and graduates were highly satisfied with the quality of the PharmD program in the United States but their level of anxiety regarding employment was high. Majority of the current students and graduates desired to stay in the United States after graduation due to better compensation, opportunity for professional development, and preferences of lifestyle in the United States. Conclusion: Academic and career advising of international students during pharmacy school and establishing a network of US PharmD graduates in Korea could serve as valuable resources for Korean international students and graduates.
\end{abstract}

Key words: PharmD, Korean, International student, Career, United States.

\section{INTRODUCTION}

During 2014-2015, a total of 974,926 international students studied at U.S colleges and universities, which constituted $4.8 \%$ of the total US higher education population. ${ }^{1}$ While majority $(40.9 \%)$ of international students pursued undergraduate degrees, $37.2 \%$ of the international students were enrolled in graduate programs. ${ }^{1}$ As such, steady number of international applicants are seeking educational opportunities in the U.S Doctor of Pharmacy (Pharm.D) program. According to Taylor et al,2 among the 85,754 applications submitted to US pharmacy schools during 2013-2014 for the first professional degree Pharm.D program, 3,641 (4.2\%) of them were submitted by international students. In 2014, 303 international students received their Pharm.D degrees in the United States, which was 2.2\% of the total first professional Pharm.D recipients.
As steady number of international students are seeking Pharm.D degree in the United States, understanding these students' background, matriculation pathways into the US Pharm.D program, reflections of the academic program, and selection of their career pathways would be valuable. After graduating with a Pharm.D degree, many possible career pathways are available in the United States, which can be largely classified into academia, community, consulting, industry, institutions, regulatory and others. ${ }^{3}$ Among international students studying in the United States, Korean students are the third most common group of students (63,710 students during 2014-2015, which comprise of $6.5 \%$ of total international students), after Chinese (31.2\%) and Indian $(13.6 \%)$ international students. ${ }^{1}$ In Korea, the 4-year pharmacy program was restructured into the 6-year (2+4) program starting in 2009.
Submission Date : 04-02-2016 Revision Date : 04-04-2016 Accepted Date : 07-04-2016

DOI: 10.5530/ijper.50.3.5 Correspondence: Yun Jeong Lee, PharmD, PhD, BCPS

Assistant Professor, Laboratory of Clinical Pharmacy, Dankook University College of Pharmacy, 119, Dandae-ro, Dongnam-gu, Cheonan-si, Chungnam, 31116,

SOUTH KOREA. Tel: +82-41-550-1445 Fax: +82-41-559-7899 E-mail:

yunlee@dankook.ac.kr

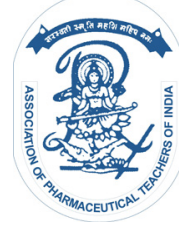

www.ijper.org 
The 6-year program was intended to allow students to cope with the changing role of pharmacists and incorporated clinical pharmacy courses and experiential rotations as part of the curriculum. ${ }^{4,5}$ With current efforts to expand the role of pharmacists in Korea, internationally well-trained clinical pharmacists who return to Korea would be essential in educating and cultivating current and future pharmacists.

To date, no studies have been conducted to characterize the international students enrolled in the traditional US Pharm.D program. In this study, characteristics and career plans of Korean international students and graduates of the U.S Pharm.D program were analyzed to help better understand this student population and provide valuable information to not only the U.S and Korean pharmacist community, but also to any prospective international students to U.S pharmacy schools.

\section{METHODS}

Members of the online community for South Korean Pharm.D students and graduates were invited to participate in this voluntary, self-administered online questionnaire. This online community is a closed community of approximately 230 members and members are able to join only by invitation and confirmation of their affiliation to the U.S Pharm.D program by the online community administrative personnel. The online community is operated in Korean, and its members include both Korean citizens and those carrying other citizenships, but of Korean descent. Information regarding the study was provided on the online community, and if the participant consented to participate in the study, they were asked to answer the initial question, which confirmed their eligibility for the study. Only those who indicated himself or herself as a current student or a graduate of the U.S Pharm.D program with Korean international student status at matriculation were eligible for the study and were able to continue the questionnaire. In order to ensure that only Korean international Pharm.D students and graduates answer the questionnaire, the questionnaire was conducted in Korean.

The questionnaire consisted of 22 questions and was divided into 4 sections: demographics, admission pathway, college life, and career plans. In the demographics section, in addition to basic demographics information, country of previous degree(s) obtained and total length of stay in the United States prior to entering the Pharm.D program were collected. If the participant indicated he/she received a bachelor degree in Korea, the questionnaire asked about whether the participant had a pharmacist license in Korea. In the admission pathway section, the condition of admission, influence and main reasons for entering pharmacy school, and the most important factor in deciding on the school were inquired. In the college life section, participants were asked to rate the quality of the Pharm.D program, difficulty of the curriculum, satisfaction level of college life, anxiety over licensure exam and anxiety over employment on a 5-point scale. Participants were also questioned about efforts made as students for employment and whether they wanted to stay in the United States or return to Korea and the reasoning behind it. For the career plans section, different sets of questions were asked based on respondents' current status. For students, their short-term (1 2 years after graduation) and long-term career plans were inquired. For graduates, their current employment status, long-term career aspirations, and current visa status in the United States were asked and for those who indicated that they are employed in Korea, a question was asked about whether pharmacist license was obtained in Korea.

The survey was conducted from November $15^{\text {th }}$ to $30^{\text {th }}$, 2014 and the participants who completed the questionnaire were incentivized to a chance of winning one of ten $\$ 10$ gift cards by random drawing. The questionnaire and research proposal have been reviewed by the Dankook University institutional review board and have been qualified as an exempt study. All data were analyzed using Microsoft Excel 2013 and responses regarding students versus graduates' career plans were compared using the nonparametric Mann-Whitney Rank Sum Test by Sigma Plot 13.0 (Systat Software, Chicago, IL, US).

\section{RESULTS}

Of the 230 members of the online community, there were 95 returned responses (participation rate of $41.3 \%$ ), and 71 met the eligibility criteria with 69 responses that were filled out and considered usable.

\section{Demographics}

The mean age of the 69 respondents were $26.4 \pm$ 4.8 years (current students $24.5 \pm 3.2$ and graduates $29.5 \pm 5.4)$ and $72.5 \%$ were females. Current students composed of $59.4 \%$ of the respondents while the graduates were $40.6 \%$, and their graduate year ranged from 2009 to 2014. Mean length of stay in the United States prior to entering the Pharm...D program was $5.0 \pm 2.8$ years (range $0-13$ ) (Table 1). Fifty eight percent of the respondents indicated that they graduated high school in the United States compared to $36.2 \%$ in Korea. Majority $(56.5 \%)$ of the respondents did not obtain a bachelor 
Table 1: Basic demographics of respondents $(\mathrm{N}=69)$

\begin{tabular}{|c|c|c|}
\hline Variable & N & (\%) \\
\hline Age (years) & \multicolumn{2}{|l|}{} \\
\hline $19-21$ & 6 & $(8.7)$ \\
\hline $22-24$ & 26 & $(37.7)$ \\
\hline $25-27$ & 16 & $(23.2)$ \\
\hline $28-30$ & 10 & $(14.5)$ \\
\hline $31-40$ & 9 & $(13.0)$ \\
\hline$>40$ & 2 & $(2.9)$ \\
\hline Gender & & \\
\hline Male & 19 & $(27.5)$ \\
\hline Female & 50 & $(72.5)$ \\
\hline Status & & \\
\hline P1 & 8 & $(11.6)$ \\
\hline P2 & 9 & $(13.0)$ \\
\hline P3 & 15 & $(21.7)$ \\
\hline P4 & 9 & $(13.0)$ \\
\hline Graduate & 28 & $(40.6)$ \\
\hline
\end{tabular}

Length of stay in the US prior to PharmD program admission (years)

\begin{tabular}{|c|c|c|}
\hline 0 & 4 & $(5.8)$ \\
\hline $1-2$ & 6 & $(8.7)$ \\
\hline $3-4$ & 23 & $(33.3)$ \\
\hline $5-6$ & 19 & $(27.5)$ \\
\hline $7-8$ & 9 & $(13.0)$ \\
\hline$\geq 9$ & 8 & $(11.6)$ \\
\hline
\end{tabular}

Degree obtained prior to entering PharmD program

\begin{tabular}{|c|c|c|}
\hline Bachelor & 30 & $(43.5)$ \\
\hline Master & 7 & $(10.1)$ \\
\hline Doctorate & 6 & $(8.7)$ \\
\hline
\end{tabular}

degree prior to entering pharmacy school, while among the 30 respondents who obtained a bachelor degree, most $(83.3 \%)$ of them indicated that the degree was obtained in the United States. Number of respondents who indicated that they had a master or doctorate degree were $7(10.1 \%)$ and $6(8.7 \%)$, respectively. Of the 4 respondents who indicated that they had a bachelor degree from Korea, one person had a Korean pharmacist license prior to matriculation into the US PharmD program but indicated that he/she enrolled into the traditional U.S Pharm.D program.

For graduates' visa status, $12(48.0 \%)$ indicated that they were currently on F-1 visa (visa for international academic students), 7 (28.0\%) were green card holders, 3 (12.0\%) were on $\mathrm{H}-1 \mathrm{~B}$ visa (non-immigrant work visa), 2 (8.0\%) resided in Korea and one other. Two (8.0\%) of the graduates indicated that they have obtained a pharmacist license in Korea.

\section{Admission Pathway}

Of the respondents, $36(52.2 \%)$ indicated that they completed some years of undergraduate courses prior to applying to pharmacy school while $33(47.8 \%)$ indicated that they were directly admitted from high school into a combined undergraduate and Pharm.D program. When asked about their influence behind considering pharmacy school, advice from family and friends $(81.2 \%)$ was most common, followed by personal search of pharmacy profession $(27.5 \%)$, advice from healthcare providers other than pharmacists $(14.5 \%)$, advice from pharmacists $(13.0 \%)$ and personal motivation $(13.0 \%)$ (up to 3 multiple answers were permitted). The respondents indicated that top reasons for entering pharmacy school were due to compensation of pharmacists (52.2\%), desire to become an expert in pharmacy/health-related field (46.4\%), interest in the study of pharmacy $(34.8 \%)$ and interest in science courses $(30.4 \%$ ) (up to 3 multiple answers were permitted). Most important factor in selection of pharmacy school were reputation and ranking (27.5\%), location (21.7\%), international student acceptance $(15.9 \%)$ and tuition (14.5\%) (Figure 1).

\section{College life}

When inquired on a 5-point scale, most of the respondents were highly satisfied with the quality of the Pharm.D program $(4.1 \pm 0.8)$, and felt that the difficulty of the curriculum was high $(4.2 \pm 0.6)$. The level of satisfaction of college life was medium to high $(3.6 \pm 1.0)$. While the respondents were not too anxious about the pharmacist licensure exam (3.0

Table 2: Korean international PharmD students and graduates' evaluation of college life during the US
\begin{tabular}{|c|c|c|c|c|c|c|} 
PharmD program & Very low \\
(1) & Low (2) & Medium (3) & High (4) & $\begin{array}{c}\text { Very high } \\
\text { (5) }\end{array}$ & $\begin{array}{c}\text { Mean } \\
\mathbf{( \pm ~ S D ) ~}\end{array}$ \\
\hline Quality of PharmD education & 0 & 3 & 10 & 30 & 23 & $4.1 \pm 0.8$ \\
\hline Curriculum difficulty & 0 & 0 & 8 & 37 & 21 & $4.2 \pm 0.6$ \\
\hline Satisfaction of college life & 1 & 9 & 15 & 29 & 12 & $3.6 \pm 1.0$ \\
\hline Anxiety over licensure exam & 7 & 16 & 18 & 18 & 7 & $3.0 \pm 1.2$ \\
\hline Anxiety over employment & 2 & 5 & 14 & 12 & 33 & $4.0 \pm 1.1$ \\
\hline
\end{tabular}




Table 3: Korean international PharmD students' short-term career plans and
graduates' current employment status

${ }^{*} \mathrm{p}<0.05$ between current students and graduates (Mann-Whitney Rank Sum Test).

\begin{tabular}{|c|c|c|c|}
\hline Country & Area of practice & $\begin{array}{c}\text { Current students } \\
\text { N (\%) }\end{array}$ & $\begin{array}{c}\text { Graduates } \\
\text { N (\%) }\end{array}$ \\
\hline \multirow{5}{*}{ US } & Community pharmacy & $6(15.4)$ & $6(24.0)$ \\
\hline & Hospital & $6(15.4)$ & $5(20.0)$ \\
\hline & Pharmaceutical industry & $9(23.1)$ & $3(12.0)$ \\
\hline & Academia & $5(12.8)$ & $3(12.0)$ \\
\hline & Etc & $1(2.6)$ & $4(16.0)$ \\
\hline \multirow{3}{*}{ Korea } & Community pharmacy/hospital & $4(10.3)$ & $0(0.0)$ \\
\hline & Pharmaceutical industry & $1(2.6)$ & $2(8.0)$ \\
\hline & Academia & $7(17.9)$ & $2(8.0)$ \\
\hline \multicolumn{2}{|r|}{ Total (N) } & 39 & 25 \\
\hline
\end{tabular}

\pm 1.2 , the level of anxiety over employment was high $(4.0 \pm 1.1)$ (Table 2). When asked about top areas of efforts made during pharmacy school for preparation of employment, majority $(70.1 \%)$ responded that they were engaged in internships and work experiences. Other responses were maintenance of good GPA (50.7\%), networking (43.3\%), professional organizations and attendance at conferences $(38.8 \%)$ and research $(25.4 \%$ ) (up to 3 multiple answers were permitted) (Figure 2).

\section{Career plans}

Current students and graduates were asked about their desire to return to Korea after graduation (for graduates, they were asked to indicate their intentions during pharmacy school). Of the 67 respondents, 26 (38.8\%) responded that they wanted to stay in the United States, $20(29.9 \%)$ wanted several years of post-graduate training in the United States but were undecided thereafter, $9(13.4 \%)$ wanted to return to Korea immediately, and $8(11.9 \%)$ wanted to return to Korea after several years of post-graduate training in the United States.

Thirty nine current Pharm.D students were inquired about their short-term (1 2 years after graduation) and long-term career plans. For short-term career plans, 30 students $(76.9 \%)$ responded that they would like to stay in the United States after graduation and 9 students $(23.1 \%)$ desired to return to Korea. Of those who responded that they would like to stay in the United States, 7 students $(17.9 \%)$ considered a career in community pharmacy, 6 students $(15.4 \%)$ desired residency, and 4 students $(10.3 \%)$ each desired a career in pharmaceutical company, additional degree(s) or fellowship. Of those who desired to return to Korea, 5 students $(12.8 \%)$ desired a career in pharmaceutical industry and 3 students $(7.7 \%)$ in community pharmacy/hospital 


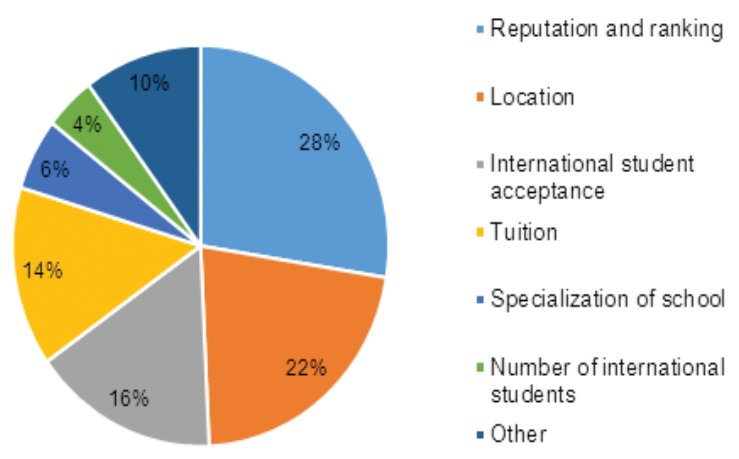

Figure 1. Korean international students' most important factor in selection of US pharmacy school.

(Table 3). For long-term career plans, 27 students $(69.2 \%)$ desired to stay in the United States and 12 students $(30.8 \%)$ desired to return to Korea. Of those who desired to stay in the United States, 9 (23.1\%) responded that they wanted to work in pharmaceutical industry, $6(15.4 \%)$ each in community pharmacy and hospital and $5(12.8 \%)$ in academia. Of those who desired to return to Korea, $7(17.9 \%)$ wanted a career in academia, $4(10.3 \%)$ in community pharmacy/hospital and one $(2.6 \%)$ in pharmaceutical industry (Table 4).

Of the 25 Pharm.D graduates, $20(80.0 \%)$ indicated that they currently work in the United States, while one $(4.0 \%)$ indicated he/she works in Korea and $4(16.0 \%)$ indicated they are not currently employed. Of the graduates in the United States, $10(40.0 \%)$ were working in community pharmacy, $2(8.0 \%)$ each were working at hospital, pharmaceutical company, academia, and completing a fellowship. Other responses included graduate school and specialty pharmacy. One graduate who was employed in Korea was working in a pharmaceutical industry (Table 3). For long-term career plans, majority of the graduates $(84.0 \%)$ wished to stay in the United States, while $16.0 \%$ wished to return to Korea. Of those who desired to stay in the United States, $6(24.0 \%)$ of the respondents wished to work at a community pharmacy, $5(20.0 \%)$ at hospital and 3 graduates (12.0\%) each desired to work in a pharmaceutical industry or academia. Other responses included specialty pharmacy, government and healthcare consulting/managed care. Of the four who wished to return to Korea, 2 (8.0\%) desired to work in a pharmaceutical industry while $2(8.0 \%)$ desired to work in academia (Table 4). Responses of students' short-term career plans to graduates' current employment status were compared and a statistical difference was seen only in the residency category (students $15.4 \%$ vs graduates $0 \%, \mathrm{p}<0.05$ ). No statistical

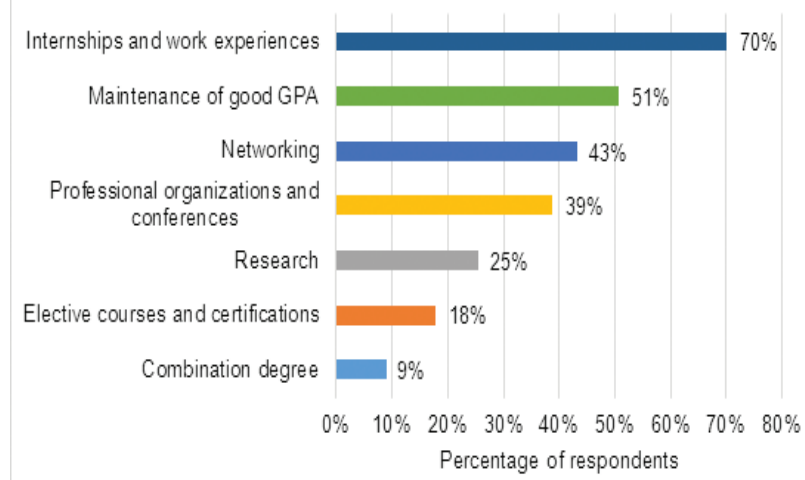

Figure 2. Top areas of efforts made by Korean international students during US pharmacy school for preparation of employment (may select up to 3 choices).

differences in the responses of long-term career goals between students and graduates were observed.

Top reasons behind desire to stay in the United States were better compensation (58.2\%), opportunity for professional development (46.3\%), and preferences of lifestyle in the United States $(37.3 \%)$, while top reasons behind desire to return to Korea were family and friends $(40.3 \%)$, desire to advance clinical pharmacy in Korea $(17.9 \%)$, difficulty of employment in the United States $(17.9 \%)$ and preference of lifestyle in Korea (16.4\%) (up to 2 choices were allowed for each question).

\section{DISCUSSION}

There is a continued increasing trend of international students studying in the United States and while the percentage of international students graduating from the US Pharm.D program has remained relatively constant over the last 10 years in the $2 \%$ range, percentage of applicants to the Pharm.D program has been in access of such rate at $3.9 \sim 5.2 \%$ in the last 4 years. ${ }^{2,6-8}$ Although the distribution of nationality of the international students enrolled in the Pharm.D program is not reported, Korean international students comprise of $3^{\text {rd }}$ largest international student group in the United States. ${ }^{1}$ Therefore, characteristics and career plans of Korean international students and graduates of the Pharm.D program in the United States were investigated to understand their characteristics, perspectives, and career plans.

Basic demographics of the respondents in this study indicate that Korean international students entering the Pharm.D program in average have spent $5.0 \pm 2.8$ years in the United States prior to entering pharmacy school and had more chance of having graduated from a high school in the United States than in Korea. Korean international students expressed that although the quality of 
the Pharm.D education was high $(4.1 \pm 0.8)$, the curriculum difficulty of the US Pharm.D program was high $(4.2 \pm 0.6)$ and their satisfaction of college life was only between medium and high $(3.6 \pm 1.0)$ while their anxiety over employment was high $(4.0 \pm 1.1)$. These results indicate that the respondents may have been struggling to maintain a high enough GPA to their standards during school. Providing attention and appropriate academic counseling to international students in the U.S PharmD program could be extremely valuable.

One of the surprising findings of this study was the extent of Korean international students' and graduates' desire to stay in the United States after graduation, as $75 \%$ desired to stay in the United States long-term. A study of STEM (science, technology, engineering, mathematics) international students in the United States found that a student's career plans after graduation provided the strongest prediction for whether a student will desire to stay in the United States. ${ }^{9}$ Students who believe that they will be treated much better by the colleagues back in their home country had more chance of leaving the United States. ${ }^{9}$ In fact, Korean respondents indicated that top reasons to stay in the United States were better compensation $(58.2 \%)$, opportunity for professional development $(46.3 \%)$, and preferences of lifestyle in the United States (17.9\%). While the US Bureau of Labor Statistics reported pharmacists' median pay in the United States as $\$ 120,950 / \mathrm{yr}$ in $2014,{ }^{10}$ Korea Employment Information Service's Occupational Information 2013 reported pharmacists' median in Korea as $\quad 50,000,000 / \mathrm{yr}$ (equivalent to approximately $\$ 43,000 / \mathrm{yr}),{ }^{11}$ which is 2.8 -fold less than that of the United States. In addition, the Korean society is based on the Confucian principles and absolute obedience to elders, teachers and superiors are obligatory. ${ }^{12}$ Furthermore, educational achievements are emphasized as this is often considered to play a role in the determination of class status ${ }^{12}$ and Koreans are grown under intense competition among peers from a young age. As the respondents in this study have spent about 5 years on average prior to matriculation into the U.S Pharm.D program, it is possible that many prefer the less strict and intense lifestyle in the U.S and prefer to stay in the US. Conversely, top reasons for wanting to return to Korea included not only personal reasons such as ties to family and friends (40.3\%) and preference of lifestyle in Korea $(16.4 \%)$ but also difficulty of employment in the United States $(17.9 \%)$. Finding a job for international students without U.S citizenship or permanent residency has become extremely challenging in the recent years. Even after international applicants go through the extremely competitive process of finding a position that sponsors the $\mathrm{H}-1 \mathrm{~B}$ visa (non-immigrant work visa), which allows nonimmigrant workers to work in the United States, there is no guarantee that the $\mathrm{H}-1 \mathrm{~B}$ visa will be given, as there is a lottery system to determine who will receive the $\mathrm{H}-1 \mathrm{~B}$ visa among many applicants. In fiscal year 2016, USCIS received nearly 233,000 H-1B petitions for the total of 85,000 available $\mathrm{H}-1 \mathrm{~B}$ visas. ${ }^{12}$ Therefore, finding an employment and obtaining the $\mathrm{H}-1 \mathrm{~B}$ visa can be a very challenging and unpredictable process for international graduates.

In a recent study, Pharm.D graduates from eight US midwestern schools of pharmacy were surveyed and it was observed that $83 \%$ of the graduates indicated community pharmacy and 13\% indicated hospital pharmacy as their desired setting of practice, while only $1 \%$ each indicated industry or ambulatory care. ${ }^{14}$ In the present study, while majority of the respondents who desired a career in the United States preferred clinical pathways of community pharmacy or hospital/ residency, many also expressed interest in industry/ fellowship, academia, or obtaining additional degrees. It can be hypothesized that the difference in the extent of the desired areas of practice in the United States might be influenced by considering a career pathway that could be more favorable to staying long-term in the United States after graduation.

Among those who wished to return to Korea, majority of the current students desired a career in a pharmaceutical industry for short-term goals $(55.6 \%)$ and a career in academia for long-term goals (58.3\%). Of the graduate respondents, 4 desired to return to Korea long-term, 2 each desiring a career in pharmaceutical industry and in academia. Preference for pharmaceutical industry in Korea could be contributed to the fact that US Pharm.D graduates do not have a Korean pharmacist license upon returning to Korea, working in the pharmaceutical industry could be an alternative way for Korean males to serve the mandatory military service in Korea in special cases, and graduates might expect a merit of having a Pharm.D degree in the pharmaceutical industry whereas in community pharmacy or hospital, such merit might not always be apparent. In the long-term, Korean students and graduates desired a career in academia in Korea. As a matter of fact, within the last 5 years, many Korean graduates of the U.S Pharm.D programs have accepted faculty positions in Korea, especially in the field of clinical pharmacy. Being in academia could be highly rewarding as there are opportunities to educate and train future pharmacists and contribute to the advancement of clinical pharmacy in Korea, especially at this time with the recent restruc- 
turing of the pharmacy education ${ }^{4}$ and continued expansion in the role of clinical pharmacists in Korea. ${ }^{15}$ Of the graduate respondents, almost half $(48.0 \%)$ of the respondents were on F-1 visa. International students are given an opportunity to apply for optional practical training (OPT) while on F-1 visa, which authorizes them up to 12 months of full-time practical training related to the major area of their study, which can be done during school or immediately after graduation. Therefore, it can be assumed that most of these graduates have graduated pharmacy school within one year and they would have to obtain an H-1B visa to work in the United States for longer than one year after graduation.

Limitations of this study include a potential for selection bias of the participants due to the nature of the online survey participation. However, this survey method was one of the most effective ways of encouraging participation of not only Korean students but also graduates from pharmacy schools in various regions of the United States. Another limitation is not having a formal confirmation process of the participants' eligibility criteria. In order to minimize the chance of non-eligible participants from answering the survey, the survey was open only to the online community for current and previous US Pharm.D graduates, conducted in Korean, and only those who indicated themselves as student or graduate of the US PharmD program with Korean international student status at matriculation were able to continue on the survey. Lastly, the survey did not utilize the validated scales for well-studied concepts such as anxiety, which could be utilized in future studies to more objectively assess the respondents' status.

From this study, it can be deduced that international students in the Pharm.D program can greatly benefit from close counseling from the college of pharmacy on their academic performance and career exploration process. For prospective international students to the U.S Pharm.D program, it should be kept in mind that while various barriers were pointed out for Korean international Pharm.D students in the United States, there are ample opportunities for growth and development as pharmacists after obtaining the Pharm.D degree, both in the United States and back home. As finding a position with an international student status in the United States pose challenges, pharmacist community in Korea can expect more US Pharm.D graduates to return to Korea. For those returning to Korea, developing a community of US Pharm.D graduates - similar to the one formed online for Korean international Pharm.D students in the U.S - could help establish a valuable network of connections and help to explore various career opportunities available in Korea.

Suggested future studies include a longitudinal study of U.S Pharm.D international students to assess the changes in the anxiety or satisfaction level over the academic period, as well as expanding the study subjects to all international students in the U.S Pharm.D program and comparing their characteristics by country of origin.

\section{CONCLUSIONS}

This is the first study that analyzed the characteristics and career plans of Korean international students and graduates of the U.S Pharm.D program. Findings from this study suggest that most of the Korean students and graduates were highly satisfied with the Pharm.D program in the United States and they desired to stay in the United States after graduation, but they faced challenges in job search as non-U.S citizen status in the United States.

Academic and career advising of international students during pharmacy school and establishing a network of U.S Pharm.D graduates in Korea could serve as valuable resources for Korean students and graduates in the U.S Pharm.D program as they navigate through pharmacy school and career exploration process.

\section{ACKNOWLEDGEMENTS}

The present research was conducted by the research fund of Dankook University in 2014.

The author would like to sincerely thank Dr. KwangChul Oh for providing valuable advice throughout the study.

\section{CONFLICT OF INTEREST}

The author has no conflicts of interest to declare.

\section{ABBREVIATIONS USED}

GPA: grade point average; Pharm.D: Doctor of Pharmacy; U.S: United States.

\section{REFERENCES}

1. Institute of International Education. Open Doors 2015 [online]. 2015 [cited 2016 Jan 4]. Available from: URL: www.iie.org/opendoors.

2. Taylor JN, Taylor DA, Nguyen NT. The pharmacy student population: applications received 2013-14, degrees conferred 2013-14, fall 2014 enrollments. Am J Pharm Educ. 2015;79(5):S3.

3. Briefing document, APhA Career Pathway Evaluation Program ${ }^{\circledR}$ for Pharmacy Professionals. American Pharmacists Association [online]. 2007 
(cited 2016 Apr 6). Available from: URL: http://www.pharmacist.com/aphacareer-pathway-evaluation-program-pharmacy-professionals.

4. Korean Pharmaceutical Association. Six-year pharmacy curriculum (online). (cited 2015 Aug 10). Available from: URL: http://www.kpanet.or.kr/.

5. Kim E, Ghimire S. Career perspectives of future graduates of the newly implemented 6-year pharmacy educational system in South Korea. Am J Pharm Educ. 2013;77(2):37.

6. Taylor DA, Taylor JN. The pharmacy student population: applications received 2010-11, degrees conferred 2010-11, fall 2011 enrollments. Am J Pharm Educ. 2012;76(6):S2.

7. Taylor DA, Taylor JN. The pharmacy student population: applications received 2011-12, degrees conferred 2011-12, fall 2012 enrollments. Am J Pharm Educ. 2013;77(6):S3.

8. Taylor DA, Taylor JN. The pharmacy student population: applications received 2012-13, degrees conferred 2012-13, fall 2013 enrollments. Am J Pharm Educ. 2014;78(7):S2.

9. Han X, Stocking G, Gebbie MA, Appelbaum RP. Will they stay or will they go? International graduate students and their decisions to stay or leave the U.S. upon graduation. PLoS One. 2015;10(3):e0118183.
10. Bureau of Labor Statistics. Occupational outlook handbook: pharmacists [online]. 2015 (cited 2016 Jan 4). Available from: URL: http://www.bls.gov/ ooh/healthcare/pharmacists.htm.

11. Korea Employment Information Service. 2013 Korea Occupational Outlook (online). 2013 (cited 2015 Aug 10). Available from: URL: http://www.keis. or.kr/user/extra/msain/712/publication/publicationList/jsp/LayOutPage. do? categoryldx=125\&publdx=1005\&spage=1.

12. Lee KS, Carrasquillo A. Korean college students in the United States: perceptions of professors and students. Coll Stud J. 2006;40(2):442-56.

13. U.S. Citizenship and Immigration Services. USCIS completes the H-1B cap random selection process for FY 2016 (online). 2015 (cited 2016 Jan 4). Available from: URL:http://www.uscis.gov/news/alerts/uscis-completes-h-1bcap-random-selection-process-fy-2016.

14. Sweet BV, Kelley KA, Janke KK, et al. Career placement of Doctor of Pharmacy graduates at eight U.S. mid western schools. Am J Pharm Educ. 2015;79(6):88.

15. Lee BK. Korea Society of Health-System Pharmacists! Thirty years of growth and new challenges. JK or Soc Health-Syst Pharm. 2012;29(1):110

\section{SUMMARY}

- Sixty nine Korean international students and graduates of the U.S Pharm.D program responded to the questionnaire to examine their characteristics and career plans.

- Korean international students in the U.S Pharm.D program were more likely to have graduated high school in the United States and had a mean of $5.0 \pm 2.8$ years stay in the United States prior to entering pharmacy school.

- Most of the Korean international students were highly satisfied with the quality of the Pharm.D program, but felt that the difficulty of the curriculum was high, and their level of anxiety over employment was also high.

- For both short- and long-term career plans, Korean international students and graduates were more likely to desire a career in the United States.

- Academic and career advising of international students during pharmacy school and a network of U.S Pharm.D graduates in Korea could serve as valuable resources for Korean international students and graduates. 